\title{
Severe COVID-19 virus reactivation following treatment for B cell acute lymphoblastic leukemia
}

\author{
Guido Lancman, John Mascarenhas and Michal Bar-Natan*
}

\begin{abstract}
SARS-CoV-2 has infected millions of people worldwide, but little is known at this time about second infections or reactivation. Here, we report a case of a 55-year-old female undergoing treatment for CD20+ B cell acute lymphoblastic leukemia who experienced a viral reactivation after receiving rituximab, cytarabine, and dasatinib. She was initially hospitalized with COVID-19 in April and developed a high antibody titer with two negative nasal polymerase chain reaction (PCR) swabs for SARS-CoV-2 on discharge. After recovery, she resumed treatment in June for her leukemia, which included rituximab, cytarabine, and dasatinib. She promptly lost her COVID-19 antibodies, and her nasal PCR turned positive in June. She developed a severe COVID-19 pneumonia with lymphopenia, high inflammatory markers, and characteristic bilateral ground-glass opacities on chest $C T$, requiring high-flow nasal cannula and transfer to the intensive care unit. She received steroids, anticoagulation, and convalescent plasma, and within $48 \mathrm{~h}$ she was off oxygen. She was discharged home in stable condition several days later. Given the short time frame from leukemia treatment to PCR positivity and the low case rate in mid-June in New York City, reinfection appears to have been unlikely and SARS-CoV-2 reactivation is a possible explanation. This case illustrates the risks of treating recently recovered COVID-19 patients with immunosuppressive therapy, particularly lymphocyte- and antibody-depleting therapy, and raises new questions about the potential of SARS-CoV-2 reactivation.
\end{abstract}

Keywords: COVID-19, SARS-CoV-2, Reactivation, Rituximab, Cytarabine

\section{To the editor}

SARS-CoV-2 has currently infected over 10 million people worldwide with over 500,000 deaths. However, little is known about reactivation of SARS-CoV-2. Although positive polymerase chain reaction (PCR) for SARS-CoV-2 following two negative PCR tests has been reported in up to $14-21 \%$ of patients $[1,2]$, these new positive tests occurred within 30 days of the last negative test and were thought to represent prior false negative PCR results and the consequence of prolonged viral shedding. There are sporadic reports to date of clinical COVID-19 virus reactivation. Ye et al. reported 5 patients with clinical

*Correspondence: Michal.Bar-Natan@mssm.edu

Tisch Cancer Institute, Icahn School of Medicine At Mount Sinai, 1

Gustave Levy Place, New York, NY 10029, USA reactivation presenting mostly with fatigue and fever, but none of them developed severe COVID-19 pneumonia or died [3]. Ravioli et al. reported two elderly patients who developed COVID-19, recovered and tested negative by PCR, and then developed a new COVID-19 pneumonia, with one patient dying and the other remaining hospitalized at the time of the report [4].

Here, we report a case of severe COVID-19 virus reactivation following chemotherapy, including rituximab, cytarabine, and dasatinib for B cell acute lymphoblastic leukemia (B-ALL). A 55-year-old female with diabetes mellitus, coronary artery disease, and asthma was diagnosed with Philadelphia chromosome-positive, CD20positive B-ALL in November of 2019. She underwent induction and consolidation per the EWALL regimen [5], with the addition of rituximab given CD20 positivity. original author(s) and the source, provide a link to the Creative Commons licence, and indicate if changes were made. The images or other third party material in this article are included in the article's Creative Commons licence, unless indicated otherwise in a credit line to the material. If material is not included in the article's Creative Commons licence and your intended use is not permitted by statutory regulation or exceeds the permitted use, you will need to obtain permission directly from the copyright holder. To view a copy of this licence, visit http://creativecommons.org/licenses/by/4.0/. The Creative Commons Public Domain Dedication waiver (http://creativeco mmons.org/publicdomain/zero/1.0/) applies to the data made available in this article, unless otherwise stated in a credit line to the data. 
She was in a complete remission from her leukemia when she presented to the emergency department on April 8 with fever and abdominal pain and was diagnosed with COVID-19 by nasopharyngeal PCR. As she had mild symptoms, she was discharged home; however, she was readmitted on April 20 due to persistent fevers, dry cough, abdominal pain, nausea, and vomiting. She had high inflammatory markers and bilateral ground-glass opacities on CT of the chest (Table 1). She received hydroxychloroquine and azithromycin per institution guidelines at that time with no improvement, then received remdesivir with clinical improvement, and was discharged home after 18 days with resolution of these symptoms. Upon discharge, a negative nasopharyngeal PCR for SARS-CoV-2 was documented (May 7) which was repeated 4 days later (May 11) and again confirmed negative. On May 14 she was tested for COVID-19-specific antibodies and demonstrated a high titer at 1:960.

As she was thought to have recovered from COVID-19, she resumed consolidation therapy for B-ALL on June 8 , receiving rituximab, cytarabine, and dasatinib. On June 18 , she was admitted to the hospital due to fevers up to $40.3^{\circ} \mathrm{C}\left(104.5^{\circ} \mathrm{F}\right)$, sore throat, abdominal pain, bloody diarrhea, and neutropenia. SARS-CoV-2 nasopharyngeal
PCR was positive; however, this was thought to be a reflection of residual viral shedding. She had a CT that showed typhlitis and marked improvement of previous lung infiltrates. She was also diagnosed with Clostridium difficile colitis at that time. Her white blood cell count reached a nadir of $0.1 \times 10^{3} / \mathrm{uL}$ from chemotherapy on June 24 . By June 27 she continued to have high fevers and developed a new cough, followed by respiratory decompensation requiring high-flow nasal cannula and transfer to the intensive care unit. Her chest CT showed extensive, diffuse ground-glass opacities at different sites from the initial COVID-19 pneumonia. Inflammatory markers were again extremely elevated (Table 1). COVID-19 antibody testing showed complete lack of COVID-19 antibodies, despite prior titer of 1:960. PCR testing remained positive on June 28 . She received 2 units of convalescent plasma and dexamethasone and was proned with rapid improvement in oxygen requirements. She was weaned off high-flow nasal cannula within $48 \mathrm{~h}$ and within a few days was discharged home in stable condition.

The immune response toward SARS-CoV-2 comprises both the cellular and humoral arms. One recent study surveyed immune responses in 36 people recovering from COVID-19 and found $\mathrm{T}$ cells that recognize

Table 1 Timeline of events from initial COVID-19 diagnosis to second COVID-19 episode

\begin{tabular}{|c|c|c|c|c|c|c|c|c|c|}
\hline Date & $4 / 8 / 20$ & $4 / 25 / 20$ & $5 / 7 / 20$ & $5 / 11 / 20$ & $5 / 14 / 20$ & $6 / 8 / 20$ & $6 / 18 / 20$ & $6 / 25 / 20$ & $6 / 28 / 20$ \\
\hline SARS-CoV-2 PCR & Positive & Positive & Negative & Negative & & & Positive & & Positive \\
\hline COVID-19 antibodies & & Positive (1:80) & & & Positive (1:960) & & & Negative & \\
\hline COVID-19 symptoms & & $\begin{array}{l}\text { Fever, cough, } \\
\text { abdominal } \\
\text { pain, nausea, } \\
\text { vomiting } \\
\text { No oxygen } \\
\text { requirement }\end{array}$ & & & & & & & $\begin{array}{l}\text { Fever, acute respiratory } \\
\text { distress requiring } \\
\text { high-flow nasal } \\
\text { cannula }\end{array}$ \\
\hline $\begin{array}{l}\text { White blood cell count } \\
\left(\times 10^{3} / \mathrm{uL}\right)\end{array}$ & 3.5 & 11.7 & 5.0 & & & 10.6 & 3.5 & 0.3 & 4.6 \\
\hline $\begin{array}{l}\text { Absolute lymphocyte } \\
\text { count }\left(\times 10^{3} / \mathrm{uL}\right)\end{array}$ & 1.9 & 1.4 & 1.6 & & & 2.6 & 0.2 & 0.1 & 0.1 \\
\hline $\begin{array}{l}\text { C-reactive protein } \\
(\mathrm{mg} / \mathrm{L})\end{array}$ & & 168.1 & 9.2 & & & & & & 314.3 \\
\hline $\begin{array}{l}\text { Erythrocyte sedimen- } \\
\text { tation rate }(\mathrm{mm} / \mathrm{h})\end{array}$ & & & & & & & & & $>145$ \\
\hline Ferritin (ng/mL) & & 4569 & 3662 & & & & & & $>33,511$ \\
\hline Interleukin 6 (pg/mL) & & 93.4 & & & & & & & 139.0 \\
\hline Fibrinogen (mg/dL) & & 603 & 567 & & & & & & 710 \\
\hline D-dimer ( $\mu \mathrm{g} / \mathrm{mL}$ FEU) & & 0.83 & 0.39 & & & & & & 3.54 \\
\hline CT chest findings & & $\begin{array}{l}\text { Moderate, bilat- } \\
\text { eral, scattered } \\
\text { ground-glass } \\
\text { opacities }\end{array}$ & & & & & & & $\begin{array}{l}\text { Extensive, diffuse } \\
\text { ground-glass opaci- } \\
\text { ties including previ- } \\
\text { ously unaffected sites }\end{array}$ \\
\hline Leukemia treatment & & & & & & $\begin{array}{l}\text { Rituximab } \\
\text { Cytarabine } \\
\text { Dasatinib }\end{array}$ & & & \\
\hline
\end{tabular}


SARS-CoV-2 in all of them [6]. A meta-analysis of 24 studies (3,099 patients) confirmed that lymphopenia is a prevalent finding and predicts disease severity [7]. B cells capable of producing neutralizing antibodies that recognize SARS-CoV-2 were reported in people who had recovered from COVID-19, and convalescent plasma therapy produces improvements in patients' clinical symptoms and radiological and biochemical parameters [8].

Many aspects of COVID-19 remain under investigation, including possible mechanisms of reactivation. In this case, the patient had high levels of COVID-19 antibodies until treatment with rituximab, an anti-CD20 antibody that is known to deplete B cells and is a known risk factor for other viral reactivations. She also received cytarabine which caused her white blood cell count to decline to $0.1 \times 10^{3} / \mathrm{uL}$ immediately preceding the second pneumonia. Given the short time frame from rituximab and cytarabine administration to PCR positivity and the low case rate in mid-June in New York City, reinfection appears to have been unlikely. Although there are no published data on PCR sensitivity, it is estimated to be anywhere from $70-95 \%$. This would allow the possibility that the patient had two false negative nasopharyngeal PCR results, although this would not account for the loss of antibodies. It is also possible that the patient never fully cleared the virus from the lower respiratory tract as sputum samples have been shown to be positive longer than upper respiratory samples [9]. A different sanctuary site could be a possibility, but this has not been identified yet for SARS-CoV-2. This case illustrates the risks of treating recovered COVID-19 patients with immunosuppressive therapy, particularly lymphocyte- and antibodydepleting therapy, and raises new questions about the potential of SARS-CoV-2 reactivation.

\section{Abbreviations}

B-ALL: B cell acute lymphoblastic leukemia; PCR: Polymerase chain reaction.

\section{Acknowledgements}

None.

\section{Authors' contributions}

GL and MBN wrote the initial draft; JM revised the manuscript. All authors read and approved the final manuscript.

\section{Funding}

No funding.

Availability of data and materials

Not applicable.

Ethics approval and consent to participate

Not applicable.

\section{Consent for publication}

Patient consented to publication of case report.

\section{Competing interests}

The authors declare that they have no competing interests.

Received: 28 July 2020 Accepted: 24 September 2020

Published online: 02 October 2020

References

1. Xiao AT, Tong YX, Zhang S. False-negative of RT-PCR and prolonged nucleic acid conversion in COVID-19: rather than recurrence. J Med Virol. 2020. https://doi.org/10.1002/jmv.25855.

2. Yuan J, Kou S, Liang Y, et al. PCR assays turned positive in 25 discharged COVID-19 patients. Clin Infect Dis. 2020;ciaa398.

3. Ye G, Pan Z, Pan Y, et al. Clinical characteristics of severe acute respiratory syndrome coronavirus 2 reactivation. J Infect. 2020;80(5):e14-7.

4. Ravioli S, Ochsner H, Lindner G. Reactivation of COVID-19 pneumonia: a report of two cases. J Infect. 2020;S0163-4453(20):30279-86.

5. Rousselot P, Coudé MM, Gokbuget N, et al. Dasatinib and low-intensity chemotherapy in elderly patients with Philadelphia chromosome-positive ALL. Blood. 2016;128(6):774-82.

6. Le Bert N, Tan AT, Kunasegaran K, et al. SARS-CoV-2-specific T cell immunity in cases of COVID-19 and SARS, and uninfected controls. Nature. 2020;584(7821):457-62.

7. Huang I, Pranata R. Lymphopenia in severe coronavirus disease-2019 (COVID-19): systematic review and meta-analysis. J Intensive Care. 2020;8:36.

8. Bakhtawar N, Usman M, Khan MMU. Convalescent plasma therapy and its effects on COVID-19 patient outcomes: a systematic review of current literature. Cureus. 2020;12(8):e9535.

9. Wölfel R, Corman VM, Guggemos W, et al. Virological assessment of hospitalized patients with COVID-2019. Nature. 2020;581:465-9.

\section{Publisher's Note}

Springer Nature remains neutral with regard to jurisdictional claims in published maps and institutional affiliations.

\footnotetext{
Ready to submit your research? Choose BMC and benefit from:

- fast, convenient online submission

- thorough peer review by experienced researchers in your field

- rapid publication on acceptance

- support for research data, including large and complex data types

- gold Open Access which fosters wider collaboration and increased citations

- maximum visibility for your research: over $100 \mathrm{M}$ website views per year

At BMC, research is always in progress.

Learn more biomedcentral.com/submissions
} 